\title{
Article \\ Diversity and Seasonal Dynamics of Airborne Fungi in Nerja Cave, Spain
}

\author{
Valme Jurado ${ }^{1}{ }^{(\mathbb{B}}$, Yolanda Del Rosal ${ }^{2}$, Cristina Liñan ${ }^{2,3}$, Tamara Martin-Pozas ${ }^{4}(\mathbb{D}$, \\ Jose Luis Gonzalez-Pimentel ${ }^{5}$ (D) and Cesareo Saiz-Jimenez ${ }^{1, *(D)}$ \\ 1 Instituto de Recursos Naturales y Agrobiologia, IRNAS-CSIC, 41012 Sevilla, Spain; vjurado@irnase.csic.es \\ 2 Instituto de Investigacion Cueva de Nerja, 29787 Nerja, Spain; yolanda@cuevadenerja.es (Y.D.R.); \\ cbaena@cuevadenerja.es (C.L.) \\ 3 Departamento de Ecologia y Geologia, Facultad de Ciencias, Universidad de Malaga, 29071 Malaga, Spain \\ 4 Museo Nacional de Ciencias Naturales, MNCN-CSIC, 28006 Madrid, Spain; tmpozas@mncn.csic.es \\ 5 Laboratorio Hercules, Universidade de Evora, 7000-809 Evora, Portugal; pimentel@irnas.csic.es \\ * Correspondence: saiz@irnase.csic.es
}

Citation: Jurado, V.; Del Rosal, Y.;

Liñan, C.; Martin-Pozas, T.;

Gonzalez-Pimentel, J.L.; Saiz-Jimenez

C. Diversity and Seasonal Dynamics of Airborne Fungi in Nerja Cave,

Spain. Appl. Sci. 2021, 11, 6236.

https://doi.org/10.3390/app11136236

Academic Editors: Filomena De Leo and Daniela Isola

Received: 16 June 2021

Accepted: 1 July 2021

Published: 5 July 2021

Publisher's Note: MDPI stays neutral with regard to jurisdictional claims in published maps and institutional affiliations.

Copyright: () 2021 by the authors. Licensee MDPI, Basel, Switzerland. This article is an open access article distributed under the terms and conditions of the Creative Commons Attribution (CC BY) license (https:// creativecommons.org/licenses/by/ $4.0 /)$.

\begin{abstract}
Nerja Cave, Southern Spain, was revealed as an important biodiversity reservoir from which several novel species of Aspergillus were described. We carried out an aerobiological study in Nerja Cave to assess the origin of airborne fungi. This study quantified the fungi present in the air of ten representative halls covering the three sectors comprising the cave: Touristic Galleries, High Galleries, and New Galleries. Microclimatological monitoring allowed us to understand the dynamic of airborne fungi in two seasons of the year (winter and summer), corresponding to the strongest and the lowest cave ventilation, and to validate the influence that the transport of airborne fungi from outside may have on the cave itself. The data show that cold air enters in winter, as confirmed by the abundant presence of Aspergillus and Penicillium spores inside and outside the cave. In summer, the abundance of some fungi in the air of Nerja Cave, which are not detected outside, indicates a stagnation or low ventilation, and therefore, the concentration of fungal spores is maxima. The high occurrence of Cladosporium outside the cave and the scarce abundance inside support the cave stagnation in this season.
\end{abstract}

Keywords: aerobiology; airborne fungi; Aspergillus; Penicillium; Parengyodontium; entomopathogenic fungi

\section{Introduction}

One of the most important topics in the conservation of caves with Paleolithic paintings is the assessment of the microbial communities inhabiting speleothems, rocks, water pools and air. A wide diversity of approaches on cave fungi can be found in the literature [1-6] and aerobiological studies were introduced as a management tool to control airborne fungi in caves with paintings [7-10].

Microclimate control and monitoring of gases $\left(\mathrm{CO}_{2}, \mathrm{CH}_{4},{ }^{222} \mathrm{Rn}\right.$, etc.) are used to investigate cave aerodynamic and ventilation or stagnation periods [11-17]. These studies, in combination with aerobiology, can provide clues for controlling airborne fungi and dispersion patterns in the caves $[18,19]$.

The microbiology of Nerja Cave, Southern Spain, was studied regarding the impact of lighting on the development of phototrophic communities [20-24], but scarcely from an aerobiological point of view. A preliminary study carried out by Del Rosal et al. [25] was focused on the survey of pathogenic bacteria and the genus Aspergillus, very abundant in the cave air in summer. Further studies by Docampo et al. [26,27] using nonviable Hirst-type volumetric pollen traps located near the entrance and at the end of the visited area found that Aspergillus/Penicillium were the most abundant spore types, representing $50 \%$ of the total, followed by Cladosporium. However, the morphology of the spores, studied 
by microscopy, does not allow distinguishing between Aspergillus and Penicillium nor the identification of species.

The main objective of this aerobiological study was to assess the presence of airborne fungi in the cave to elucidate its origin. The identification of fungi was carried out by molecular methods. The study quantified the fungi present in the air from 10 representative halls covering the three sectors composing the cave: Touristic Galleries, High Galleries, and New Galleries. A sampling point outside the cave was used as a control of environmental fungi. This monitoring allowed to know the dynamic of airborne fungi in two seasons of the year (winter and summer), corresponding to the strongest and the lowest cave ventilation, and to validate the influence that the transport of airborne fungi from outside may have on the cave itself.

\section{Materials and Methods}

\subsection{Site Description}

Nerja Cave is one of the biggest and most important show caves in Spain, with a volume of about $300,000 \mathrm{~m}^{3}$, almost $5 \mathrm{~km}$ of passages, and more than 400,000 visitors annually. It is also one of the most significant prehistoric sites in Europe, with more than 500 artistic representations. About a third of the cave, the Touristic Galleries, is open to the public since 1960. The other two sections, named High Galleries and New Galleries, only can be accessed by researchers.

The climate of the area is coastal Mediterranean, with an average precipitation slightly lower than $500 \mathrm{~mm} \mathrm{yr}^{-1}$. The external air average temperature ranges from about $13^{\circ} \mathrm{C}$ to $26^{\circ} \mathrm{C}$ (January and August, respectively), with an average annual value of $18.8^{\circ} \mathrm{C}$ [28].

The cave is developed within fissured and karstified Triassic dolomitic marbles more than $500 \mathrm{~m}$ thick at the unsaturated zone of the Sierra Almijara carbonate massif. A significant portion of the dolomitic marbles is devoid of vegetation. The soil cover is scarce, with a thickness lower than $0.15 \mathrm{~m}$, and the natural vegetation consists mainly of shrubs and pine trees. However, in the areas nearest to the touristic entrance, there are several gardens with many ornamental plants [29], and thus, the vegetation cover is much more developed over the Touristic Galleries than over the nonvisited sector.

The cavity develops between 123 and $191 \mathrm{~m}$ a.s.l. According to the outside orography, rock thickness above the cave varies from 4 to $50 \mathrm{~m}$ in the area open to tourism, and exceeds $80 \mathrm{~m}$ in the nonvisited area. The cavity has three natural entrances: an entrance with a semicircular form and about $12 \mathrm{~m}^{2}$ of surface (E1 in Figure 1), which is used for the access and exit of visitors and two subcircular sinkholes (E2 and E3 in Figure 1).

Nerja Cave is connected to at least two other nearby cavities, Pintada Cave (PC)—a small cavity with a natural entrance located to $250 \mathrm{~m}$ a.s.l-_and another great and nonaccessible cave from the surface (GC), found recently with indirect methods [13]. Although there is no speleological connection between these three caves, they are effectively linked for air circulation patterns from the surface.

Four ventilation regimes (winter, summer, spring, and autumn) and two ventilation modes with opposite airflows direction (named DAF- and UAF-modes) were defined in Nerja Cave karstic system during the annual cycle [13]. In all the cases, the natural ventilation of the system is determined by variations in the differences of density between the external and internal air. 


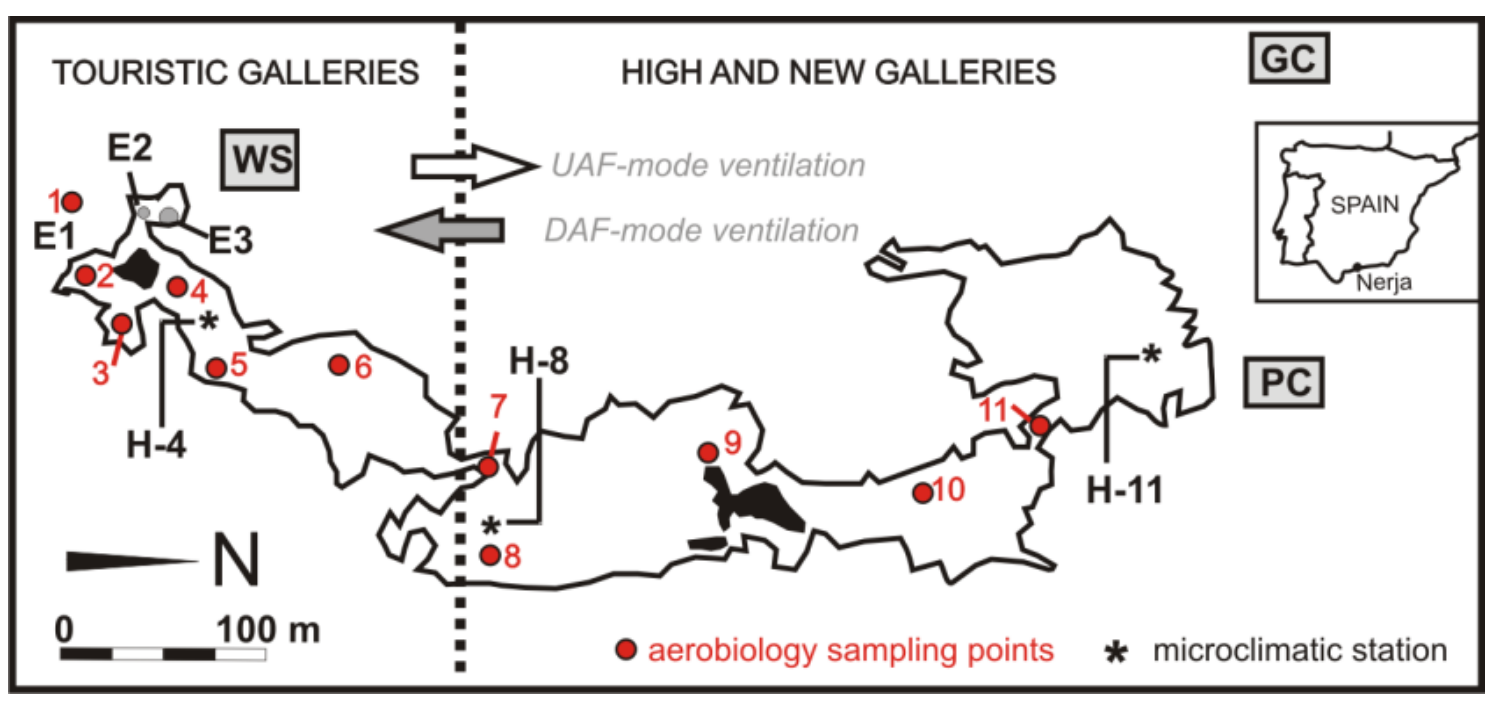

Figure 1. Cave map and location of the aerobiology sampling points and microclimatic stations. 1: Cave Exterior, 2: Entrance Hall, 3: Nativity Hall, 4: Cascade Hall, 5: Ghosts Hall, 6: Cataclysm Hall, 7: Kitchen Hall, 8: Heracles Hall, 9: Immensity Hall, 10: Lance Hall, 11: Mountain Hall. PC: Pintada Cave, GC: non accessible cave from surface, WS: weather station, E1: tourist entrance, E2 and E3: sinkholes. Location of PC, GC, and WS is approximate.

\subsection{Microclimatology}

Nerja Cave has a microclimatic monitoring network (Figure 1) consisting of dataloggers CR1000 (Campbell Scientific) with probes measuring air $\mathrm{CO}_{2}$ concentration, air temperature, and relative humidity, amongst other parameters, at hourly intervals. Air temperature and relative humidity were measured with a probe HMP155A- Vaisala (measuring ranges: $0-100 \%$ and -80 to $+60{ }^{\circ} \mathrm{C}$; accuracy: $\pm 1.0 \%$ and $\pm 0.17^{\circ} \mathrm{C}$ ). Cave air $\mathrm{CO}_{2}$ concentrations were measured using an infrared absorption sensor (GMM222-Vaisala; measuring range $0-5000 \mathrm{ppmv}$, accuracy $\pm 1.5 \%$ ).

The ${ }^{222} \mathrm{Rn}$ concentration of cave air was registered every $30 \mathrm{~min}$ using a Radim $5 \mathrm{WP}$ radon monitor (GT-Analytic KG). The detectable activity is between $80 \mathrm{~Bq} / \mathrm{m}^{3}$ and $150 \mathrm{KBq} / \mathrm{m}^{3}$ (for one-hour measurements with a statistical error $\pm 20 \%$ ) (Table 1 ).

The environmental data of the external air were provided by the instrumental equipment placed in the weather station (WS in Figure 1) located a few meters from Nerja Cave entrances.

\subsection{Aerobiology}

Two sampling campaigns were carried out on 9 July 2016 and 12 January 2017. These two campaigns corresponded to the stronger ventilation (winter, UAF-mode ventilation) and lower ventilation (summer, DAF-mode ventilation) periods, previously described by Liñán et al. [13]. In each sampling, a total of 10 control sites were selected inside and one outside the cave. The sites sampled were: Touristic Galleries (Entrance Hall, Nativity Hall, Cascade Hall, Ghosts Hall, Cataclysm Hall), High Galleries (Kitchen Hall, Heracles Hall, Immensity Hall), and New Galleries (Lance Hall and Mountain Hall), in addition to the exterior air (Figure 1).

Samplings were performed with a Duo SAS (Surface Air System) Super 360 system (International pBI, Milan, Italy). This equipment is a type of suction impact collector that was widely used in aerobiological studies $[8,10]$. It allows the detection of a great diversity of cultivable fungi by filtering a preselected volume of air through two heads provided with a series of orifices, which impact upon Petri dishes.

At each sampling site, samples were taken in duplicate. The volume of filtered air was $100 \mathrm{~L}$ in $35 \mathrm{~s}$. This volume was established because at higher volumes the number of spores was too high for an accurate count [8]. The culture medium used to promote fungal growth was dichloran rose bengal-chloramphenicol-agar (DRBCA, Merck, Darmstad, Germany). 
The Petri dishes were incubated at $25^{\circ} \mathrm{C}$ and after 5 days counted. After counting, the fungi were isolated, cultured and the DNA extracted.

The methodology was thoroughly described by Sanchez-Moral et al. [19] and Dominguez-Moñino et al. [30]. DNA was extracted from the mycelia of each fungal strain. Mycelia were scraped from the plates and transferred to a $1.5 \mathrm{~mL}$ Eppendorf tube containing $500 \mu \mathrm{l}$ lysing buffer and $200 \mu \mathrm{l}$ glass beads. The mixture was shaken in a cell disrupter (Fast Prep-24, Solon, OH, USA) at full speed for $3 \mathrm{~min}$.

Fungal internal transcribed spacer (ITS) regions, including ITS1, 5.8S rDNA and ITS2, were amplified using the primers ITS1 (5'-TCCGTAGGTGAACCTGCGG-3 ${ }^{\prime}$ ) and ITS4 (5'-TCCTCCGCTTATTGATATGC-3'). Amplification protocol comprised one cycle of denaturation $\left(94{ }^{\circ} \mathrm{C}\right.$ for $2 \mathrm{~min}$ ), followed by 35 cycles of denaturation $\left(94{ }^{\circ} \mathrm{C}\right.$ for $\left.1 \mathrm{~min}\right)$, and a terminal elongation step $\left(72{ }^{\circ} \mathrm{C}\right.$ for $\left.5 \mathrm{~min}\right)$.

PCR products were analyzed by Macrogen Inc. (Amsterdam, The Netherlands) and sequenced using the same primer set. For phylogenetic identification of fungal strains, the sequences were compared using BLASTn algorithm with nonredundant databases of sequences deposited at the National Center for Biotechnology Information (http:/ / www.ncbi.nlm.nih.gov/). The sequences are available from the GenBank database under accession numbers: MZ374012-MZ374055 and MZ375763-MZ375863.

\section{Results}

\subsection{Microclimatology}

Table 1 shows the main statistical parameters of the microclimatic data recorded outside (WS) and inside the cave: Cascade Hall (H-4), Heracles Hall (H-8), and Mountain Hall (H-11) for the period 2016-2017. The external air temperature ranged between 7.27 and $30.34{ }^{\circ} \mathrm{C}$, with a mean value $(\mathrm{m})$ of $18.93^{\circ} \mathrm{C}$. The relative humidity ranged from 29 to $94 \%$, with a mean value of $67 \%$.

Table 1. Microclimatic data registered in Nerja Cave, Spain, and the exterior atmosphere during 2016 and 2017.

\begin{tabular}{|c|c|c|c|c|c|c|c|c|}
\hline & WS & H-4 & H-8 & H-11 & WS & $\mathrm{H}-4$ & H-8 & H-11 \\
\hline & \multicolumn{4}{|c|}{ Air Temperature $\left({ }^{\circ} \mathrm{C}\right)$} & \multicolumn{4}{|c|}{ Relative Humidity (\%) } \\
\hline$n$ & 731 & 727 & 600 & 731 & 731 & 688 & 600 & 731 \\
\hline $\max$ & 30.34 & 20.08 & 19.66 & 19.92 & 93.68 & 98.11 & 99.77 & 100.00 \\
\hline $\min$ & 7.27 & 18.15 & 19.18 & 19.75 & 28.92 & 54.40 & 81.11 & 100.00 \\
\hline$m$ & 18.93 & 19.21 & 19.40 & 19.86 & 67.08 & 84.49 & 95.21 & 100.00 \\
\hline$s$ & 4.80 & 0.60 & 0.13 & 0.04 & 11.69 & 12.27 & 4.96 & 0.00 \\
\hline$v(\%)$ & 25.33 & 3.10 & 0.69 & 0.19 & 17.43 & 14.53 & 5.21 & 0.00 \\
\hline \multirow[t]{3}{*}{ range } & 22.88 & 1.93 & 0.48 & 0.16 & 65.00 & 43.71 & 18.66 & 0.00 \\
\hline & WS & H-4 & H-8 & H-11 & WS & H-4 & H-8 & H-11 \\
\hline & \multicolumn{4}{|c|}{ Air $\mathrm{CO}_{2}(\mathrm{ppmv})$} & \multicolumn{4}{|c|}{$\operatorname{Air}{ }^{222} R n\left(B q / m^{3}\right)$} \\
\hline$n$ & 223 & 688 & 600 & 731 & nd & 1379 & nd & nd \\
\hline $\max$ & 518 & 1483 & 1170 & 986 & nd & 622 & nd & nd \\
\hline $\min$ & 436 & 489 & 512 & 499 & nd & 80 & nd & nd \\
\hline$m$ & 474 & 797 & 699 & 633 & nd & 213 & nd & nd \\
\hline S & 19 & 226 & 158 & 111 & nd & 161 & nd & nd \\
\hline$v(\%)$ & 4 & 28 & 23 & 18 & nd & 76 & nd & nd \\
\hline range & 83 & 994 & 657 & 487 & nd & 542 & nd & nd \\
\hline
\end{tabular}

Legends: exterior weather station (WS), Cascade Hall (H-4), Heracles Hall (H-8), Mountain Hall (H-11), $n-$ number of measures, max-maximum value, min-minimum value, $m$-mean value, $s$-standard deviation, $v$ (\%)—variation coefficient, nd-not measured. Data "Air $\mathrm{CO}_{2}$ " registered in exterior correspond to year 2018, and

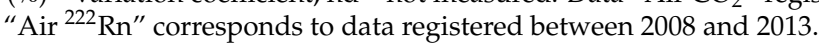


Inside the cave, the air temperature in $\mathrm{H}-4$ hall ranged between 18.15 and $20.08{ }^{\circ} \mathrm{C}$ $\left(m=19.21^{\circ} \mathrm{C}\right)$ and the relative humidity ranged between $54 \%$ and $98 \%(m=85 \%)$. The air $\mathrm{CO}_{2}$ content ranged from 489 to 1483 ppmv, with a mean value of $797 \mathrm{ppmv}$.

In the $\mathrm{H}-11$ hall, the air temperature ranged between 19.75 and $19.92^{\circ} \mathrm{C}\left(m=19.86{ }^{\circ} \mathrm{C}\right)$ so the difference between the maximum and minimum temperatures was lower than $0.2^{\circ} \mathrm{C}$ (Table 1). The air $\mathrm{CO}_{2}$ content ranged from 499 to 986 ppmv, with a mean value of 633 ppmv. The air relative humidity was $100 \%$ during all the studied period.

In $\mathrm{H}-8$ intermediate values of air temperature $\left(m=19.40^{\circ} \mathrm{C}\right)$ and relative humidity ( $m=95 \%$ ) were recorded. In this case, the air $\mathrm{CO}_{2}$ content ranged from 512 to $1170 \mathrm{ppmv}$, with a mean value of 699 ppmv. Therefore: (1) the air of the tourist sector is colder, less wet, and has a higher $\mathrm{CO}_{2}$ content than in that of the nonvisited galleries of Nerja Cave, (2) the temperature and relative humidity variability is noticeably reduced in the nonvisited sector, located below greater thickness of rock and at greater distances from the cave entrances (E1, E2 and E3 in Figure 1), and (3) the variation coefficients ( $v$ in Table 1$)$ in the external media are higher than in the cave, except for air $\mathrm{CO}_{2}$.

Figure 2 shows the temporal evolution of the main environmental parameters relative to the external air and cave air during 2016 and 2017. In summer, the temperature of the external air $\left(\mathrm{T}_{\text {ext }}\right)$ is higher than that of the cave air $\left(\mathrm{T}_{\mathrm{int}}\right)$, and the latter is denser than the exterior (Figure 2A,B). $\mathrm{CO}_{2}$ concentrations in the Touristic Galleries (Figure 2C) reach maximum values, coinciding with a lower index of natural ventilation (daily average values of ${ }^{222} \mathrm{Rn}$ over the $400 \mathrm{~Bq} / \mathrm{m}^{3}$, Figure $2 \mathrm{~A}$ ) and a greater number of visitors (Figure $2 \mathrm{~B}$ ).

Air relative humidity is high in the cave, with values ranging between 95 and 100\% (Figure 2D). When the external temperature markedly exceeds the cave temperature $\left(\Delta \mathrm{T}>5.0^{\circ} \mathrm{C}\right)$ the DAF-mode ventilation is activated (yellow orange bars in Figure 2). The cave air, denser than the external air, is blown out by the lowest entrances, and atmospheric air is sucked in by the highest entrances. During the day corresponding to the summer campaign (9 July 2016), $\Delta \mathrm{T}$ was $7.53{ }^{\circ} \mathrm{C}$ (daily average value).

In winter, the external air is generally colder and denser than the cave air, although exceptionally short-term periods exist in which $\mathrm{T}_{\text {ext }}>\mathrm{T}_{\text {int }}$ (Figure $2 \mathrm{~A}, \mathrm{~B}$ ). $\mathrm{CO}_{2}$ concentrations inside the Touristic Galleries are minimal and much more similar to those of the external atmosphere (Figure 2C), given the more effective natural ventilation (daily average values of ${ }^{222} \mathrm{Rn}$ of $80 \mathrm{~Bq} / \mathrm{m}^{3}$ ) and lower number of visitors.

Cave air relative humidity is minimum in the Touristic Galleries and shows the same temporal evolution than the external air (Figure 2D). When $T_{\text {ext }}<T_{\text {int }}$, the external air, denser and colder than the internal air, easily enters Nerja Cave through the lowest entrances, moves through the Touristic Galleries, arrives at the High and New Galleries (the same day or 1-2 days later), and finally leaves the cave through Pintada Cave. During the day corresponding to the winter campaign (12 January 2017), the daily average value of $\Delta \mathrm{T}$ was $-5.30^{\circ} \mathrm{C}$. 

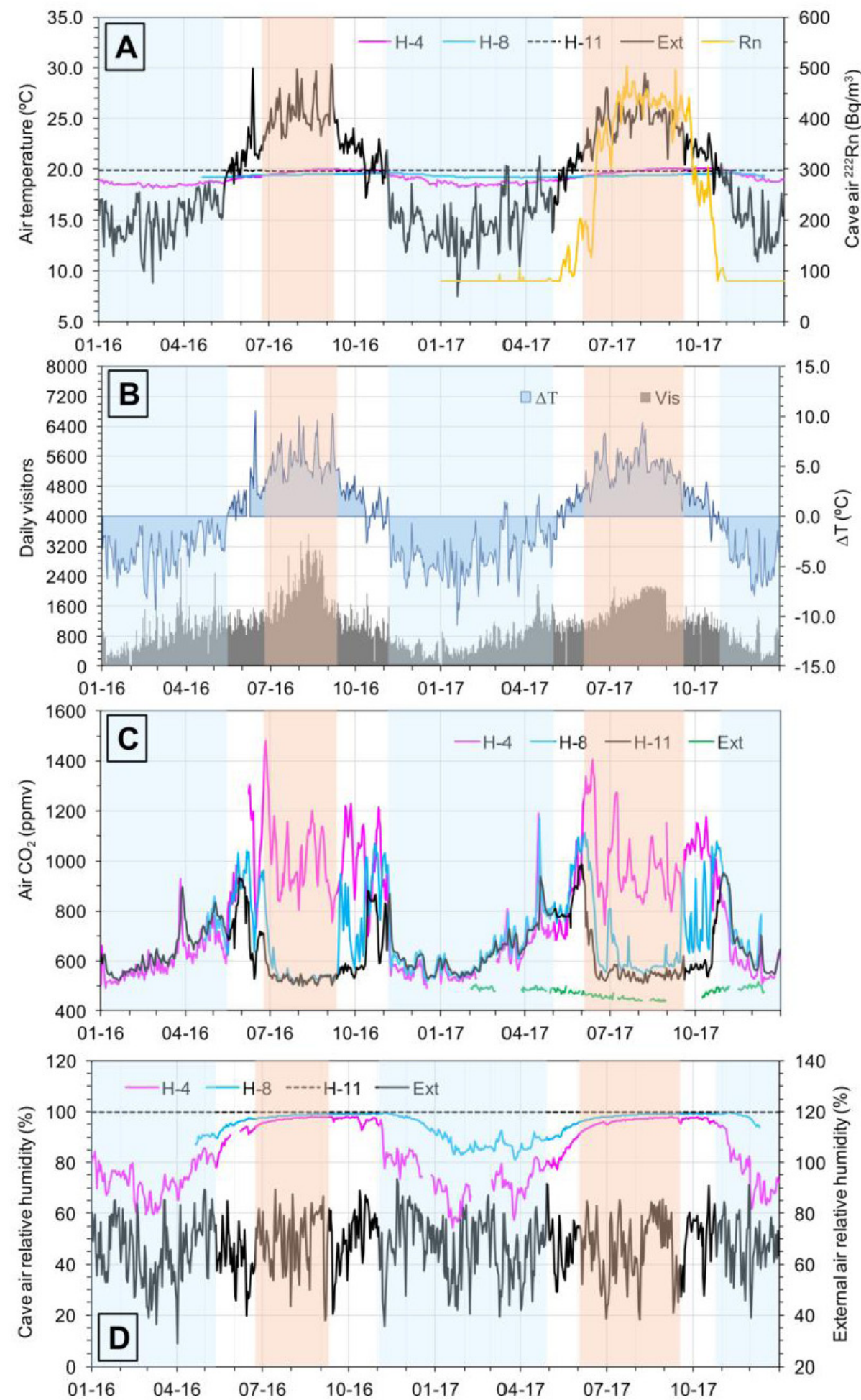

Figure 2. Daily evolution from $01 / 01 / 16$ to $31 / 12 / 17$ of (A) external and cave air temperatures in Nerja Cave versus air ${ }^{222} \mathrm{Rn}$ concentration in H-4 (average for the period 2008-2013); (B) daily visitors versus air temperature differences $\left(\Delta \mathrm{T}=\mathrm{T}_{\text {ext }}-\mathrm{T}_{\text {int }}\right) ; \mathrm{T}_{\text {ext }}$ : external air temperature; $\mathrm{T}_{\text {int }}$ : internal air temperature (H-4); (C) air $\mathrm{CO}_{2}$ content. Data of external air $\mathrm{CO}_{2}$ correspond to year 2018 and (D) external and cave air relative humidity. Blue bars: winter ventilation period, UAF-mode. Yellow orange bars: summer ventilation period, DAF-mode. 


\subsection{Aerobiology}

Two aerobiological samplings were performed to cover the aerodynamic periods in Nerja Cave (Figure 3): high ventilation, corresponding to the winter station (12 January 2017), and very low ventilation produced in the summer station (9 July 2016).

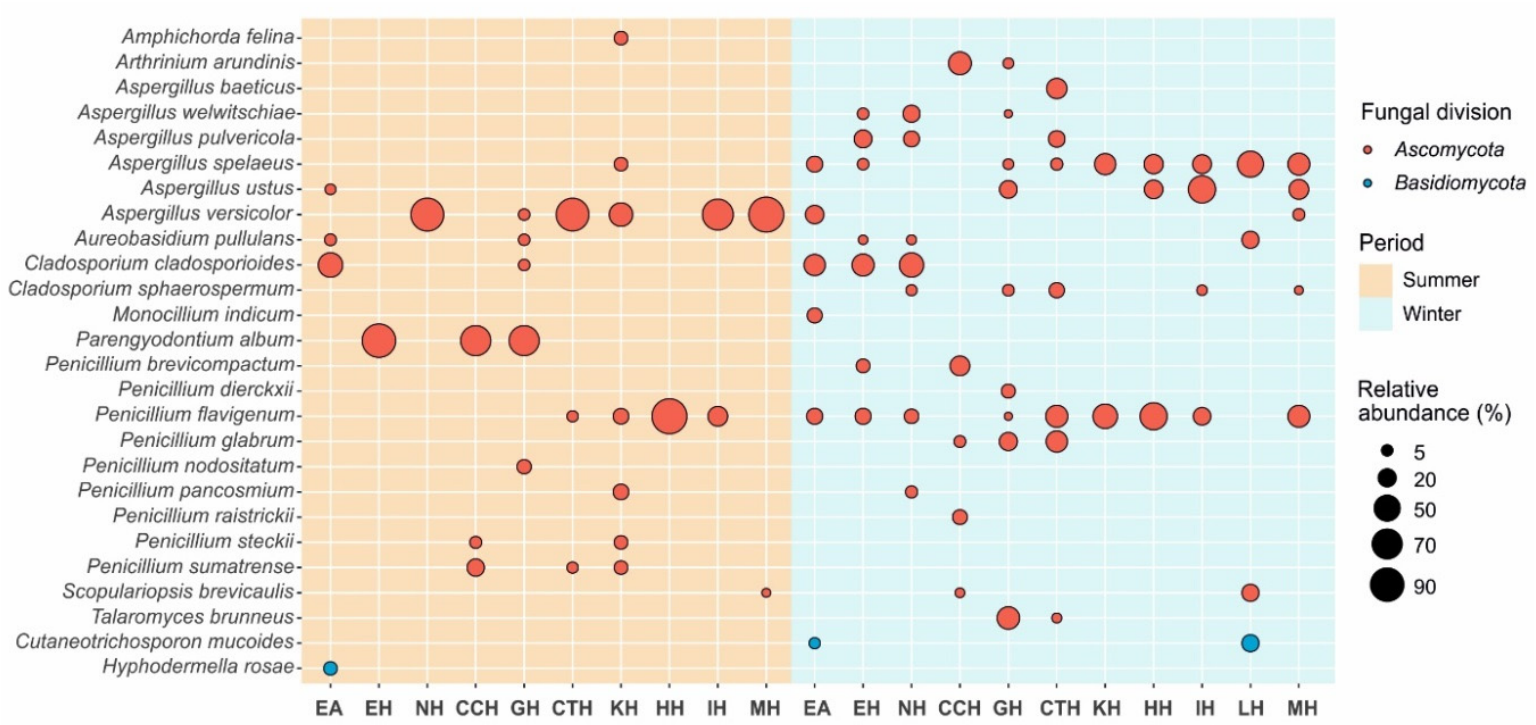

Figure 3. Bubble Plot. Most abundant fungi, as distributed in each sampling point (EA: Outside, EH: Entrance Hall, NH: Nativity Hall, CCH: Cascade Hall, GH: Ghosts Hall, CTH: Cataclysm Hall, KH: Kitchen Hall, HH: Heracles Hall, IH: Immensity Hall, LH: Lance Hall, MH: Mountain Hall) and period (summer and winter).

The concentration of fungal spores outside was relatively high in summer and near the half in winter. In general, the concentration of fungal spores in all the galleries was considerably lower in the summer period with respect to the higher ventilation period, as shown in Tables 2 and 3. Inside the cave, the fungal patterns were different depending on the galleries trail.

Two behaviors were distinguished: in the Touristic Galleries, fungal spore abundances increased between 2- and 5-times in winter, while the figures were greater (from 7- to 133-times in the High and New Galleries).

Remarkable were the low concentrations in the Lance Hall (Table 3), while in the Kitchen and Heracles halls, they were very high. Obviously these abundances should be related with definite sources and/or the aerodynamic of the halls.

\subsubsection{Summer Campaign, 9 July 2016}

The lower ventilation period (summer) is characterized by the abundant presence of spores of three genera, Parengyodontium, Aspergillus, and Penicillium. Other less abundant genera were Cladosporium, Alternaria, Aureobasidium, Bipolaris, and Amphichorda (Table 2). In total, 16 different species were retrieved inside the cave and 13 outside.

Parengyodontium album was only limited to the visited Touristic Galleries: Entrance, Cascade, and Ghosts Halls, where reached abundances between 70 and $90 \%$. However, Aspergillus versicolor, also abundant, was distributed across the three galleries: Touristic (Nativity and Ghosts Halls), High (Kitchen and Immensity Halls), and New (Mountain Hall).

Other Aspergillus species was A. spelaeus, only identified in the Kitchen Hall. Six species of Penicillium were collected in the Touristic and High Galleries, from which the abundances of $P$. flavigenum, $P$. sumatrense, $P$. pancosmium, and $P$. nodositatum were above $10 \%$ in any of the halls and those of P. citreosulfuratum and P. steckii below $10 \%$. Interestingly, P. flavigenum was the unique fungus in Heracles Hall and A. versicolor in Mountain Hall. 
Outside, none of the most abundant fungi inside the cave could be identified, and only Cladosporium cladosporioides (43.06\% outside and 5.0\% inside) and Aureobasidium pullulans (5.56\% outside and 5.0\%) were represented in the Ghosts Hall, and Alternaria tenuissima in the Nativity Hall (6.67\%).

Table 2. Total counts, identifications, and abundance of fungi isolated from Nerja Cave in 2016 summer campaign.

\begin{tabular}{|c|c|c|c|}
\hline Sampling & $\mathrm{CFU} \mathrm{\textrm {m } ^ { - 3 }}(\mathrm{SD})$ * & Identification (\% Similarity) & Abundance (\%) \\
\hline \multirow{3}{*}{$\begin{array}{l}\text { Entrance Hall } \\
\qquad(\mathrm{EH})\end{array}$} & \multirow{3}{*}{$170(40)$} & Cladosporium lebrasiae (100\%) & 6.45 \\
\hline & & Parengyodontium album (100\%) & 90.32 \\
\hline & & Penicillium citreosulfuratum (100\%) & 3.23 \\
\hline \multirow{3}{*}{$\begin{array}{l}\text { Nativity Hall } \\
\text { (NH) }\end{array}$} & \multirow{3}{*}{$80(20)$} & Alternaria tenuissima $(100 \%)$ & 6.67 \\
\hline & & Aspergillus versicolor $(100 \%)$ & 86.67 \\
\hline & & Penicillium citreosulfuratum (100\%) & 6.67 \\
\hline \multirow{4}{*}{$\begin{array}{l}\text { Cascade Hall } \\
(\mathrm{CCH})\end{array}$} & \multirow{4}{*}{$90(20)$} & Parengyodontium album (100\%) & 70.59 \\
\hline & & Phoma sp. $(99 \%)$ & 5.88 \\
\hline & & Penicillium sumatrense (100\%) & 17.65 \\
\hline & & Penicillium steckii (100\%) & 5.88 \\
\hline \multirow{6}{*}{$\begin{array}{l}\text { Ghosts Hall } \\
(\mathrm{GH})\end{array}$} & \multirow{6}{*}{$100(0)$} & Aspergillus versicolor (100\%) & 5.00 \\
\hline & & Aureobasidium pullulans (100\%) & 5.00 \\
\hline & & Bipolaris cynodontis (100\%) & 5.00 \\
\hline & & Cladosporium cladosporioides (100\%) & 5.00 \\
\hline & & Parengyodontium album (100\%) & 70.00 \\
\hline & & Penicillium nodositatum (99\%) & 10.00 \\
\hline \multirow{4}{*}{$\begin{array}{c}\text { Cataclysm Hall } \\
\text { (CTH) }\end{array}$} & \multirow{4}{*}{$110(20)$} & Aspergillus versicolor $(100 \%)$ & 85.71 \\
\hline & & Penicillium citreosulfuratum $(100 \%)$ & 4.76 \\
\hline & & Penicillium flavigenum (100\%) & 4.76 \\
\hline & & Penicillium sumatrense (100\%) & 4.76 \\
\hline \multirow{7}{*}{$\begin{array}{l}\text { Kitchen Hall } \\
(\mathrm{KH})\end{array}$} & \multirow{7}{*}{$120(10)$} & Aspergillus spelaeus (100\%) & 8.70 \\
\hline & & Aspergillus versicolor $(100 \%)$ & 39.13 \\
\hline & & Amphichorda felina $(100 \%)$ & 8.70 \\
\hline & & Penicillium flavigenum (100\%) & 13.04 \\
\hline & & Penicillium pancosmium $(100 \%)$ & 13.04 \\
\hline & & Penicillium steckii $(100 \%)$ & 8.70 \\
\hline & & Penicillium sumatrense (100\%) & 8.70 \\
\hline $\begin{array}{l}\text { Heracles Hall } \\
(\mathrm{HH})\end{array}$ & $10(0)$ & Penicillium flavigenum (100\%) & 100.00 \\
\hline \multirow{2}{*}{$\begin{array}{l}\text { Immensity Hall } \\
\text { (IH) }\end{array}$} & \multirow{2}{*}{$20(0)$} & Aspergillus versicolor (100\%) & 75.00 \\
\hline & & Penicillium flavigenum (100\%) & 25.00 \\
\hline $\begin{array}{l}\text { Lance Hall } \\
\quad(\mathrm{LH})\end{array}$ & 0 & No detected & - \\
\hline \multirow{13}{*}{$\begin{array}{l}\text { Exterior air } \\
\text { (EA) }\end{array}$} & \multirow{13}{*}{$390(60)$} & Tremateia chromolaenae (99\%) & 5.56 \\
\hline & & Victoriomyces antarcticus (100\%) & 2.78 \\
\hline & & Alternaria tenuissima $(100 \%)$ & 1.39 \\
\hline & & Aspergillus tubingensis (100\%) & 1.39 \\
\hline & & Aspergillus melleus $(100 \%)$ & 5.56 \\
\hline & & Aspergillus ustus $(100 \%)$ & 4.17 \\
\hline & & Aureobasidium pullulans (100\%) & 5.56 \\
\hline & & Botrytis cinerea $(100 \%)$ & 2.78 \\
\hline & & Cladosporium cladosporioides (100\%) & 43.06 \\
\hline & & Hyphodermella rosae $(100 \%)$ & 8.33 \\
\hline & & Microascus croci $(99 \%)$ & 5.56 \\
\hline & & Penicillium olsonii (99\%) & 5.56 \\
\hline & & Purpureocillium lilacinum (100\%) & 8.33 \\
\hline
\end{tabular}

*CFU: colony forming units; SD: standard deviation. 
Table 3. Total counts, identifications, and abundance of fungi isolated from Nerja Cave in 2017 winter campaign.

\begin{tabular}{|c|c|c|c|}
\hline Sampling & $\mathrm{CFU} \mathrm{m} \mathrm{m}^{-3}(\mathrm{SD})$ * & Identification (\% Similarity) & Abundance (\%) \\
\hline \multirow{10}{*}{$\begin{array}{l}\text { Entrance Hall } \\
\qquad(\mathrm{EH})\end{array}$} & \multirow{10}{*}{$430(10)$} & Aspergillus welwitschiae (99\%) & 5.13 \\
\hline & & Aspergillus pulvericola (99\%) & 19.23 \\
\hline & & Aspergillus spelaeus (99\%) & 5.13 \\
\hline & & Aureobasidium pullulans (100\%) & 2.56 \\
\hline & & Botrytis cinerea $(100 \%)$ & 1.28 \\
\hline & & Cladosporium cladosporioides $(100 \%)$ & 33.33 \\
\hline & & Penicillium brevicompactum (100\%) & 8.97 \\
\hline & & Aspergillus europaeus (100\%) & 2.56 \\
\hline & & Penicillium flavigenum (100\%) & 14.10 \\
\hline & & Penicillium rubens (100\%) & 7.69 \\
\hline \multirow{9}{*}{$\begin{array}{l}\text { Nativity Hall } \\
(\mathrm{NH})\end{array}$} & \multirow{9}{*}{$360(30)$} & Aspergillus welwitschiae (99\%) & 16.67 \\
\hline & & Aspergillus pulvericola (99\%) & 13.64 \\
\hline & & Aspergillus ochraceus (100\%) & 1.52 \\
\hline & & Aureobasidium pullulans (100\%) & 3.03 \\
\hline & & Botrytis cinerea $(100 \%)$ & 1.52 \\
\hline & & Cladosporium cladosporioides (100\%) & 42.42 \\
\hline & & Cladosporium sphaerospermum $(100 \%)$ & 4.55 \\
\hline & & Penicillium flavigenum $(100 \%)$ & 10.61 \\
\hline & & Penicillium pancosmium (99\%) & 6.06 \\
\hline \multirow{7}{*}{$\begin{array}{l}\text { Cascade Hall } \\
(\mathrm{CCH})\end{array}$} & \multirow{7}{*}{$190(30)$} & Arthrinium arundinis (99\%) & 36.11 \\
\hline & & Penicillium olsonii (99\%) & 5.56 \\
\hline & & Penicillium sumatrense (98\%) & 13.89 \\
\hline & & Penicillium glabrum $(100 \%)$ & 5.56 \\
\hline & & Penicillium raistrickii (99\%) & 11.11 \\
\hline & & Penicillium brevicompactum (100\%) & 25.00 \\
\hline & & Scopulariopsis brevicaulis (100\%) & 2.78 \\
\hline \multirow{10}{*}{$\begin{array}{l}\text { Ghosts Hall } \\
\text { (GH) }\end{array}$} & \multirow{10}{*}{$420(40)$} & Arthrinium arundinis (99\%) & 4.00 \\
\hline & & Aspergillus welwitschiae (99\%) & 1.33 \\
\hline & & Aspergillus spelaeus (99\%) & 4.00 \\
\hline & & Aspergillus ustus (100\%) & 18.67 \\
\hline & & Cladosporium sphaerospermum (100\%) & 5.33 \\
\hline & & Penicillium glabrum $(100 \%)$ & 20.00 \\
\hline & & Penicillium dierckxii (100\%) & 9.33 \\
\hline & & Penicillium flavigenum (100\%) & 1.33 \\
\hline & & Aspergillus oryzae $(100 \%)$ & 1.33 \\
\hline & & Talaromyces brunneus (100\%) & 34.67 \\
\hline \multirow{6}{*}{$\begin{array}{l}\text { Cataclysm Hall } \\
\text { (CTH) }\end{array}$} & \multirow{6}{*}{$180(60)$} & Aspergillus spelaeus (99\%) & 6.06 \\
\hline & & Aspergillus pulvericola $(99 \%)$ & 15.15 \\
\hline & & Cladosporium sphaerospermum (100\%) & 12.12 \\
\hline & & Penicillium flavigenum $(100 \%)$ & 33.33 \\
\hline & & Penicillium glabrum (100\%) & 30.30 \\
\hline & & Talaromyces brunneus $(100 \%)$ & 3.03 \\
\hline \multirow{3}{*}{$\begin{array}{l}\text { Kitchen Hall } \\
\qquad(\mathrm{KH})\end{array}$} & \multirow{3}{*}{$2170(130)$} & Aspergillus baeticus (100\%) & 26.91 \\
\hline & & Aspergillus spelaeus (99\%) & 30.18 \\
\hline & & Penicillium flavigenum (100\%) & 42.91 \\
\hline \multirow{3}{*}{$\begin{array}{l}\text { Heracles Hall } \\
(\mathrm{HH})\end{array}$} & \multirow{3}{*}{$1330(40)$} & Aspergillus spelaeus (99\%) & 23.50 \\
\hline & & Aspergillus ustus (100\%) & 21.50 \\
\hline & & Penicillium flavigenum (100\%) & 55.00 \\
\hline \multirow{4}{*}{$\begin{array}{l}\text { Immensity Hall } \\
\text { (IH) }\end{array}$} & \multirow{4}{*}{$140(20)$} & Aspergillus ustus (100\%) & 55.56 \\
\hline & & Aspergillus spelaeus $(99 \%)$ & 22.22 \\
\hline & & Cladosporium sphaerospermum (100\%) & 3.70 \\
\hline & & Penicillium flavigenum $(100 \%)$ & 18.52 \\
\hline
\end{tabular}


Table 3. Cont.

\begin{tabular}{|c|c|c|c|}
\hline Sampling & $\mathrm{CFU} \mathrm{\textrm {m } ^ { - 3 }}(\mathrm{SD})$ * & Identification (\% Similarity) & Abundance (\%) \\
\hline \multirow{4}{*}{$\begin{array}{l}\text { Lance Hall } \\
\text { (LH) }\end{array}$} & \multirow{4}{*}{$30(10)$} & Aspergillus spelaeus (99\%) & 50.00 \\
\hline & & Aureobasidium pullulans (100\%) & 16.67 \\
\hline & & Cutaneotrichosporon mucoides (100\%) & 16.67 \\
\hline & & Scopulariopsis brevicaulis (100\%) & 16.67 \\
\hline \multirow{6}{*}{$\begin{array}{l}\text { Mountain Hall } \\
\text { (MH) }\end{array}$} & \multirow{6}{*}{$280(0)$} & Aspergillus ustus (100\%) & 25.00 \\
\hline & & Aspergillus spelaeus (99\%) & 32.69 \\
\hline & & Aspergillus versicolor $(100 \%)$ & 5.77 \\
\hline & & Cladosporium sphaerospermum (100\%) & 1.92 \\
\hline & & Penicillium flavigenum (100\%) & 32.69 \\
\hline & & Scopulariopsis brevicaulis $(100 \%)$ & 1.92 \\
\hline \multirow{8}{*}{$\begin{array}{c}\text { Exterior air } \\
\text { (EA) }\end{array}$} & \multirow{8}{*}{$230(20)$} & Alternaria tenuissima $(100 \%)$ & 2.33 \\
\hline & & Aspergillus spelaeus (99\%) & 13.95 \\
\hline & & Aspergillus versicolor $(100 \%)$ & 20.93 \\
\hline & & Botrytis cinerea $(100 \%)$ & 2.33 \\
\hline & & Cladosporium cladosporioides (100\%) & 30.23 \\
\hline & & Cutaneotrichosporon mucoides $(100 \%)$ & 4.65 \\
\hline & & Monocillium indicum $(99 \%)$ & 11.63 \\
\hline & & Penicillium flavigenum (100\%) & 13.95 \\
\hline
\end{tabular}

*CFU: colony forming units; SD: standard deviation.

\subsubsection{Winter Campaign, 12 January 2017}

The higher ventilation period (winter) showed a great number of different species inside the cave (25), but less diversity outside (8) (Table 3). Seventeen out of 25 species attained abundance above $10 \%$ in any of the halls (Table 3). The sampling was dominated by species of Penicillium (9), Aspergillus (9), and Cladosporium (2). Single species of Arthrinium, Aureobasidium, Botrytis, Cutaneotrichosporon, Scopulariopsis, and Talaromyces were also identified. The major diversity of fungal species was found in the halls of the Touristic Galleries (7 to 10 species), middle in the New Galleries (4 to 6 species), and low in the High Galleries ( 3 and 4 species).

Abundances above $50 \%$ in any hall were observed for P. flavigenum, A. ustus, and A. spelaeus, and between 50 and $25 \%$ for $C$. cladosporioides, Arthrinium arundinis, Penicillium brevicompactum, Talaromyces brunneus, Penicillium glabrum, and Aspergillus baeticus.

Two fungi, A. spelaeus and P. flavigenum were isolated from eight halls, A. ustus from four, and Aspergillus pulvericola and P. glabrum from 3 out of 10 halls. Aspergillus was not found in Cascade Hall, nor Penicillium in Lance Hall.

Two halls, Kitchen and Heracles, showed huge spore concentrations (2170 and $1330 \mathrm{CFU} \mathrm{\textrm {m } ^ { - 3 }}$, respectively). P. flavigenum and A. spelaeus dominated in both cases, in addition to A. baeticus in Kitchen and A. ustus in Heracles halls.

In the sampling outside the cave, 6 out of 8 fungal species were also retrieved inside, and only Alternaria tenuissima and Monocillium indicum were not present in the cave air. However, A. tenuissima was also recovered inside and outside the cave in summer.

\section{Discussion}

The microclimatological study in Nerja Cave shows two well defined ventilation patterns corresponding to summer (low ventilation) and winter (high ventilation). The type of ventilation regime is closely related with the concentration of airborne fungi in the cave. In fact, the higher number of spores was observed in summer due to air stagnation or low ventilation, whereas in winter, ventilation helped to remove and/or dilute spore concentrations. Similar phenomena were described in other caves $[7,19]$.

Figure 3 shows the distribution of the most abundant fungi across the different galleries and seasons. Several patterns can be observed, namely the practical absence of Basidiomycota. This pattern is opposite to that found in caves from Northern Spain, where the input of wood-rotting Basiomycota spores related to Quercus forests predominates in the 
ventilation period (winter) [18]. In Nerja Cave's surroundings, forests and dead trees are not prevalent.

Another well-defined pattern is the higher diversity of Ascomycota in the air in winter with relatively medium spore abundances, whereas in the summer period, the abundances of a few Ascomycota (Aspergillus versicolor, Parengyodontium album, Penicillium flavigenum) were remarkable, but they were not retrieved outside the cave.

The presence of Ascomycota in the two seasons, irrespective of the high or low ventilation period, could be associated with the phototrophic biofilms. Dominguez-Moñino et al. [30] related the abundance of Parengyodontium, Aspergillus, and Penicillium in the air of Tesoro Cave (Rincon de la Victoria, Malaga) at some $40 \mathrm{~km}$ from Nerja, with the abundant biofilms of cyanobacteria and algae originated by the artificial lighting used for allowing the visits. Nerja Cave houses also abundant phototrophic biofilms near the entrance, just in the Touristic Galleries. A similar association between phototrophs and Ascomycota was reported by other authors [31,32].

The senescence and lysis of old phototrophic biofilms can provide nutrients for the fungi and lead to the abundance of airborne spores in the halls close to the cave entrance. Jurado et al. [24] reported complex trophic interactions in Nerja Cave between the components of the biofilms, including processes of predation of bacteria and amoebas, and the occurrence of nematodes, fungi, and other Eukaryota.

The higher diversity and relative abundance of Ascomycota spores in winter are consistent with the entry of air according to the ventilation mode of Nerja Cave during this period of the annual cycle. During the winter campaign, the difference $\Delta \mathrm{T}$ is negative. The colder and denser external air enters Nerja Cave through the lower entrances (E1, E2 and E3 in Figure 1) and moves from the tourist to nontourist sector (UAF-mode). So, the strong ventilation during this period contributes to the entry of atmospheric air inside the cave, to its rapid exit through the Pintada Cave, and thus, to the rapid renovation of the air cave. This is exemplified by the abundant occurrence of Cladosporium cladosporioides, Aspergillus spelaeus, and Penicillium flavigenum in the halls of the Touristic Galleries and outside.

Parengyodontium album (syn. Engyodontium album, Beauveria alba, Tritirachium album) [33], identified only in summer, was limited to the air of the visited area (Touristic Galleries), which could correspond to the presence of insects in spring and summer, since the fungus is a parasite of arthropods, and also to the presence of phototrophic biofilms in these galleries. Novakova et al. [34] found this species only in the air of the cave, but not in the sediments.

Jurado et al. [35] and Leplat et al. [36] reviewed the entomopathogenic fungi related to cultural heritage sites and associated $\mathrm{Pa}$. album with the presence of arthropods. This was also reported in Lascaux Cave [37]. Data on the role of fungi in caves suggested that the species related to arthropods contribute to their mortality and favor the dispersal of spores. Jurado et al. [35] recommended the control of arthropod populations as a method to reduce fungal contamination and colonization of substrates, sediments, and rocks [35].

The spores of $\mathrm{Pa}$. album were also widely distributed in the air of Castañar de Ibor, Ardales, Gruta de las Maravillas, and Tesoro caves [30,38,39]. In addition, Pa. album is common in other subterranean environments [40-43] and wall paintings, and in this last case associated to arthropods [44-46]. A review on cave fauna reported the presence of many different classes of arthropods in Nerja, including endemisms [47]. The abundant presence of spores of $\mathrm{Pa}$. album and other entomopathogenic fungi in the air in Ardales and Tesoro caves [30] emphasizes the likely role of arthropods as a vector of these fungi.

The genus Aspergillus is one of the most abundant in the air of Nerja Cave. Aspergillus showed greater diversity in winter, with the species $A$. versicolor, $A$. spelaeus, $A$. baeticus, $A$. ustus, $A$. pulvericola, $A$. welwitschiae, $A$. oryzae, and $A$. ochraceus, while in summer were only recovered $A$. versicolor and $A$. spelaeus.

The abundance of Aspergillus was shown in previous publications, although the species could not be identified due to the protocol used [26,27]. Novakova et al. [32] isolated 72 fungi from sediments and air in Nerja, among them 18 different species of Aspergillus, from 
which two were only present in the air and three in both sediments and air. This suggests that an important source of Ascomycota in the cave, the sediments, could not be disregarded. We isolated seven species of Aspergillus from the cave air, and the most abundant species present in the two seasonal samplings were $A$. versicolor, A. spelaeus, A. ustus, and A. baeticus. The first two showed a marked seasonality, so while $A$. versicolor was abundant in summer and scarce in winter, $A$. spelaeus showed the inverse trend, being highly represented in almost all the halls in winter and occasionally in summer (8.7\% in Kitchen Hall).

According to Gunde-Cimerman et al. [48] A. versicolor is a xerotolerant species frequently detected even in extreme environments. Aspergillus versicolor was relatively common in the air of caves all over the world [10,35,49-54], while Aspergillus ustus presented a more restricted distribution $[49,50,52,55,56]$.

Aspergillus versicolor, relatively abundant outside in winter, was only found in the deepest Mountain Hall. Thus, according to the ventilation mode of the winter period (UAF-mode), their relationship with the external atmosphere is discarded. On the contrary, $A$. versicolor is not detected outside the cave in summer, but its concentration is high inside the cave. The highest frequency of $A$. versicolor in summer, unlike other species of the genus Aspergillus, points to a relationship with the increasing of nutrient sources, i.e., phototrophic biofilms or bat droppings, and could be explained by the ventilation mode of Nerja Cave during this period of the year (DAF-mode). The colder and denser Nerja Cave air is removed through the lower entrances (E1, E2 and E3 in Figure 1) and external air is sucked in through the Pintada Cave and other nonaccessible entrances located in the Almijara range. This suction effect causes the air previously stored in the PC and the GC to reach Nerja Cave. Thus, the source of these fungi would not be the external atmosphere but the cave air previously stored in PC, GC, and other possible subterranean voids connected to Nerja Cave and located in higher altitude.

This also applies to A. spelaeus, found in 2011 with some frequency in the sediments of Nerja Cave. The study of the isolated strains established the bases for the description of these strains as a new species [57]. A subsequent visit in 2012 allowed the isolation of new strains [32,57]. As far as we know, no other records on this Aspergillus were published.

Another new species of Aspergillus isolated in Nerja was A. baeticus. This was described in 2012 [58], and the type strain was isolated from sediments from Gruta de las Maravillas (Aracena, Huelva) along with other strains from Tesoro Cave. In addition, this fungus was isolated from air, cave sediments, and a dead spider (Agraecina cristiani) in Movile Cave, as well as from a bat cadaver in Demänovska Peace Cave [59], and from cave sediments in Nerja Cave [32].

The new species Aspergillus europaeus was isolated in 2011 from soils near Nerja and Movile caves, although no isolates were obtained directly from the caves [57]. We isolated this fungus in the air of the Entrance Hall in winter, suggesting an origin from the soil outside the cave and their transport inside, according to the UAF-mode ventilation [28].

Less abundant Aspergillus species identified in the air of Nerja Cave were also recorded in different caves such as A. ochraceus [55,60-62]. No cave record was found for A. pulvericola and A. welwitschiae.

The genus Penicillium is widely distributed in caves, and in Nerja, it was recorded in the two seasonal samplings in almost all the halls; although generally with little abundance in summer, not so in winter. In summer, six species of Penicillium were recorded in all the halls except in the Lance, while in winter, a total of 10 species were recovered in all the halls but not in the Lance. This is the same trend recorded for Aspergillus; very abundant in winter, and scarce in summer.

The most abundant Penicillium species was P. flavigenum, both in summer and winter, although with marked differences in their total abundances and presence in the halls (Tables 2 and 3), and P. glabrum, which was only identified in winter. P. flavigenum and $P$. glabrum are relatively common in caves $[8,49,50,55,63-66]$. Madsen et al. [67] found that $P$. glabrum was among the three most frequent species of fungi present inside Danish houses. 
The presence of spores of Penicillium, in autumn and winter, in the air of Tesoro Cave, was important [30], as it suggests that this genus is abundant in the air of the caves of Malaga province in periods when ventilation is greater.

Relatively less abundant species compared with P. flavigenum and P. glabrum were P. sumatrense, P. steckii, P. pancosmium, P. citrosulfuratum, P. nodositatum in summer, and $P$. brevicompactum, P. rubens $P$. pancosmium, P. olsonii, $P$. sumatrense, $P$. raistrickii, and $P$. fellutanum, in winter. Moreover, similar to Aspergillus, Penicillium showed higher diversity in winter.

Talaromyces brunneus was isolated in winter from Ghosts and Cataclysm halls. The basionym is Penicillium brunneum. The references to this fungus in the literature are scarce, only to the original isolation from miller rice from Thailand [68], the production of anthraquinones [69] and the cellulolytic activity of a strain isolated from a cave [70].

In Nerja Cave, the spores of the genus Cladosporium were detected in the two seasonal samplings, both outside and inside the cave. In summer, C. cladosporioides accounted for $43.1 \%$ of all spores outdoor, but only $5.3 \%$ in the Ghosts Hall; C. lebrasiae was only found in the Entrance Hall, with $6.5 \%$ abundance, denoting clearly the existence of a low ventilation period. However, in winter, the situation changed drastically, since the concentration of C. cladosporioides spores outside was $30.2 \%$, but its abundance increased in the different halls, such as the Entrance Hall (33.3\%) and in Nativity Hall (42.2\%), as correspondent with a higher ventilation period. In addition, C. sphaerospermum was represented in Nativity (4.6\%), Ghosts (5.3\%), Cataclysm (12.1\%), Immensity (3.7\%), and Mountain (1.9\%) halls.

Garcia-Anton et al. [17] (2014) proved that in Altamira Cave Cladosporium spores had a clear external origin, as the data obtained for Nerja Cave also suggest that the presence of these fungi in the cave was due to transport from outside through air currents. It also stands out for its abundance in the air of Nerja Cave when the ventilation in the cave is greater (winter) compared to its practical absence in summer, with less or little ventilation. Likewise abundant were the species of the genus Cladosporium in the seasonal samplings (autumn and winter) in Ardales Cave [30].

The genus Cladosporium and, specifically, the species C. cladosporioides, was previously identified in the air of different European and Chinese caves [5,9,17,37,50,62,64,66,71], while C. sphaerospermum was retrieved from Slovakian and Chinese caves $[49,50,66]$. Cladosporium lebrasiae was first described from contaminated foods and forms a sister clade with Cladosporium dominicanum [72,73], but no reports on caves or air were found.

Other remarkable fungal species were Aureobasidium pullulans, Botrytis cinerea, Arthrinium arundinis, Alternaria tenuissima, Bipolaris cynodontis, all plant pathogens, but also isolated from caves $[5,32,50,61,62,74,75]$. The origin inside the cave may be due to the vegetation around the cavity. In addition, other noticeable fungi were Amphichorda felina, Cutaneotrichosporon mucoides, and Scopulariopsis brevicaulis. Amphichorda is one of the most ubiquitous entomopathogenic fungal genera. The species A. felina (syn. Beauveria felina, Isaria felina) appeared only in the Kitchen Hall with $8.7 \%$ abundance, but it deserves to be noticed for their ecology, since is a fungus colonizing animal feces in Spanish caves [76] and isolated from other caves [77,78]. Scopulariopsis brevicaulis is often recorded in indoor environments [79] and isolated from bat skin [80] as well as Cutaneotrichosporon mucoides (syn. Trichosporon mucoides), the later common in caves populated by bats [81,82]. Scopulariopsis brevicaulis was previously isolated from the air and sediments of Nerja Cave [32].

The abundance of Cladosporium cladosporioides spores in the air outside the cave is notable. Species of the genus Cladosporium are very common outdoor, at any time of the year, and also inside buildings, along with Alternaria, Aspergillus, and Penicillium. Outdoor, according to Gómez de Ana et al. [83], (2006), Cladosporium and Penicillium are very common in the four seasons of the year, but Penicillium was more abundant in winter and Aspergillus in summer. In Nerja Cave, both Penicillium and Aspergillus showed outdoor higher abundances in winter than in summer, as well as a high diversity in the cave air. However, $A$. versicolor stood out for their abundance in the cave in summer. This showed the influence that the outside air can have on the dispersal of the spores of these fungi 
inside the cave in winter and the influence of the air previously stored in other caves connected to the ventilation of Nerja Cave in summer.

Of the 18 species identified in the two seasonal air samples outside the cave, only 8 were not found inside, Tremateia chromolaenae, Victoriomyces antarcticus, Microascus croci, Hyphodermella rosae, Purpureocillium lilacinum, Monocillium indicum, Aspergillus tubingensis, and Aspergillus melleus. Hyphodermella rosae is a white-rot corticioid fungus previously isolated from La Garma Cave air [18], Purpureocillium lilacinum is an entomopathogenic fungus often isolated from caves [50,52,62,64], Monocillium indicum and Victoriomyces antarcticus were found in soils [84,85], Tremateia chromolaenae was associated with plants [86], and Microascus croci with aquatic sediments [87]. The remaining two Aspergillus spp. were isolated from Brazilian caves [88,89].

It is of interest to notice that many of the fungi isolated were reported as entomopathogens and/or associated with arthropods, including A. versicolor, A. ustus, A. ochraceus, A. olsonii, A. welwitschiae, A. tubingensis, B. cinerea, C. cladosporioides, C. sphaerospermum, Pa. album, P. flavigenum, P. chrysogenum, P. raistrickii, P. brevicompactum, P. steckii, Pu. lilacinum, and S. brevicaulis, among others [90-93].

\section{Conclusions}

The studies in Nerja and other Andalusian caves were essential for the description of new species of the genus Aspergillus [57,58], and specifically for A. spelaeus, which type strain was isolated from Nerja [94]. This suggests that these caves are reservoirs of new species of fungi as well as bacteria $[95,96]$, and their study contributes to increasing the knowledge of biodiversity on the planet.

Considering the results, the influence that the external air has on Nerja Cave during the winter is demonstrated. Cold air enters in winter, and this is confirmed by the abundant presence of Aspergillus and Penicillium spores inside the cave, without ruling out that the reservoirs of these fungi were already installed in the cave itself (sediments, phototrophic biofilms) and that the increased air flow carries away the spores. In summer, the abundance of fungal spores in Nerja Cave, which are not detected outside, as in the case of $A$. versicolor, suggests a different source for these microorganisms, linked to the nutrient sources and other subterranean voids and caves near Nerja Cave. Other seasonal events, such as the presence of entomopathogenic fungal spores in summer, were also reflected in the air of the cave.

The data reported in this work are in agreement with the findings of Docampo et al. [26,27]. These authors reported that spores of Aspergillus and Penicillium were, by far, the most abundant in the air of the cave and were retrieved throughout the year, followed by Cladosporium. The influence of the ventilation is clearly shown by the high abundances of Cladosporium spores outside the cave both in summer and winter. The high occurrence in the halls near the entrance in winter is related to ventilation, and the practical absence inside the cave in summer is due to low ventilation or stagnation period.

The conditions of access and visit to a cave have an impact due to the mobilization of air and dispersal of aerial microorganisms. However, this is minimized in the summer season, when there is a greater influx of visitors, as shown by the low concentration of spores found inside. However, the high abundance of Aspergillus and Penicillium spores in the Kitchen and Heracles halls in winter requires a more detailed study to understand their origin and nature and to be able to reduce the concentrations of spores, which are much larger than in other neighboring halls (Cataclysm and Immensity).

Author Contributions: Investigation, V.J., Y.D.R., C.L., T.M.-P., J.L.G.-P., writing-original draft preparation, C.S.-J., Y.D.R., C.L., writing-review and editing, C.S.-J. All authors read and agreed to the published version of the manuscript.

Funding: This research was funded by Nerja Cave Foundation. This work is part of an Interdisciplinary Research Project for the conservation of Nerja Cave, authorized by the Ministry of Culture of the Andalusian Government. 
Institutional Review Board Statement: Not applicable.

Informed Consent Statement: Not applicable.

Data Availability Statement: Data, under accession numbers MZ374012-MZ374055 and MZ375763MZ375863, were deposited into the GenBank database.

Acknowledgments: This paper is dedicated to the memory of Professor Wolfgang E. Krumbein (19372021) (https:/ / de.wikipedia.org/wiki/Wolfgang_E._Krumbein), an outstanding scientist and dear friend and colleague. The authors acknowledge Nerja Cave Foundation for the support and facilities and CSIC Interdisciplinary Thematic Platform Open Heritage: Research and Society (PTI-PAIS) for the professional support.

Conflicts of Interest: The authors declare no conflict of interest.

\section{References}

1. Adetutu, E.M.; Thorpe, K.; Bourne, S.; Cao, X.; Shahsavari, E.; Kirby, G.; Ball, A.S. Phylogenetic diversity of fungal communities in areas accessible and not accessible to tourists in Naracoorte Caves. Mycologia 2011, 103, 959-968. [CrossRef] [PubMed]

2. Martin-Sanchez, P.M.; Nováková, A.; Bastian, F.; Alabouvette, C.; Saiz-Jimenez, C. Use of biocides for the control of fungal outbreaks in subterranean environments: The case of the Lascaux Cave in France. Environ. Sci. Technol. 2012, 46, 3762-3770. [CrossRef]

3. Di Piazza, S.; Isaia, M.; Vizzini, A.; Badino, G.; Voyron, S.; Zotti, M. First mycological assessment in hydrothermal caves of Monte Kronio (Sicily, southern Italy). Webbia. J. Plant Taxon. Geogr. 2017, 72, 277-285. [CrossRef]

4. Man, B.; Wang, H.; Yun, Y.; Xiang, X.; Wang, R.; Duan, Y.; Cheng, X. Diversity of fungal communities in Heshang Cave of Central China revealed by mycobiome-sequencing. Front. Microbiol. 2018, 9, 1400. [CrossRef] [PubMed]

5. Ogórek, R.; Kozak, B.; Visnovská, Z.; Tancinová, D. Phenotypic and genotypic diversity of airborne fungal spores in Demänovská Ice Cave (Low Tatras, Slovakia). Aerobiologia 2018, 34, 13-28. [CrossRef] [PubMed]

6. Pusz, W.; Król, M.; Zwijacz-Kozica, T. Airborne fungi as indicators of ecosystem disturbance: An example from selected Tatra Mountains caves (Poland). Aerobiologia 2018, 34, 111-118. [CrossRef] [PubMed]

7. Wang, W.; Ma, X.; Ma, Y.; Mao, L.; Wu, F.; Ma, X.; An, L.; Feng, H. Seasonal dynamics of airborne fungi in different caves of the Mogao Grottoes, Dunhuang. China. Int. Biodeter. Biodegr. 2010, 64, 461-466. [CrossRef]

8. Porca, E.; Jurado, V.; Martin-Sanchez, P.M.; Hermosin, B.; Bastian, F.; Alabouvette, C.; Saiz-Jimenez, C. Aerobiology: An ecological indicator for early detection and control of fungal outbreaks in caves. Ecol. Indic. 2011, 11, 1594-1598. [CrossRef]

9. Fernandez-Cortes, A.; Cuezva, S.; Sanchez-Moral, S.; Porca, E.; Jurado, V.; Saiz-Jimenez, C. Detection of human-induced environmental disturbances in a show cave. Environ. Sci. Pollut. Res. 2011, 18, 1037-1045. [CrossRef]

10. Martin-Sanchez, P.M.; Jurado, V.; Porca, E.; Bastian, F.; Lacanette, D.; Alabouvette, C.; Saiz-Jimenez, C. Airborne microorganisms in Lascaux Cave (France). Int. J. Speleol. 2014, 43, 295-303. [CrossRef]

11. Carrasco, F.; Vadillo, I.; Liñan, C.; Andreo, B.; Durán, J.J. Control of environmental parameters for management and conservation of Nerja Cave (Malaga, Spain). Acta Carsologica 2002, 31, 105-122. [CrossRef]

12. Liñán, C.; Vadillo, I.; Carrasco, F. Carbon dioxide concentration in air within the Nerja Cave (Malaga, Andalusia, Spain). Int. J. Speleol. 2008, 37, 99-106. [CrossRef]

13. Liñán, C.; Ojeda, L.; Benavente, J.; Del Rosal, Y.; Vadillo, I.; Carrasco, F. Coupling air temperature records and gravimetric data to interpret ventilation patterns in a Mediterranean karstic system (Nerja-Pintada caves, southern Spain). Sci. Total Environ. 2020, 730, 139147. [CrossRef] [PubMed]

14. Benavente, J.; Vadillo, I.; Liñan, C.; Carrasco, F.; Soler, A. Ventilation effects in a karstic show cave and in its vadose environment, Nerja, Southern Spain. Carbonates Evapotites 2011, 26, 11-17. [CrossRef]

15. Dueñas, C.; Fernández, M.C.; Cañete, S.; Pérez, M.; Gordo, E. Seasonal variations of radon and the radiation exposure levels in Nerja cave, Spain. Radiat. Meas. 2011, 46, 1181-1186. [CrossRef]

16. Del Rosal, Y.; Liñan, C.; Hernandez-Marine, M. The conservation of the Nerja Cave: Preserving anthropogenic impact in a tourist cave. In The Conservation of Subterranean Cultural Heritage; Saiz-Jimenez, C., Ed.; CRC Press/Balkema: Leiden, The Netherlands, 2014; pp. 193-206.

17. Ojeda, L.; Vadillo, I.; Etiope, G.; Benavente, J.; Liñán, C.; Del Rosal, Y.; Tapia, S.T.; Moríñigo, M.A.; Carrasco, F. Methane sources and sinks in karst systems: The Nerja cave and its vadose environment (Spain). Geochim. Cosmochim. Acta 2019, 259, 302-315. [CrossRef]

18. Garcia-Anton, E.; Cuezva, S.; Jurado, V.; Porca, E.; Miller, A.Z.; Fernandez-Cortes, A.; Saiz-Jimenez, C.; Sanchez-Moral, S. Combining stable isotope $\left({ }^{13} \mathrm{C}\right)$ of trace gases and aerobiological data to monitor the entry and dispersion of microorganisms in caves. Environ. Sci. Pollut. Res. 2014, 21, 473-484. [CrossRef] [PubMed]

19. Sanchez-Moral, S.; Jurado, V.; Fernandez-Cortes, A.; Cuezva, S.; Martin-Pozas, T.; Gonzalez-Pimentel, J.L.; Ontañon, R.; SaizJimenez, C. Environment-driven control of the dispersal of fungi in subterranean ecosystems: The case of La Garma Cave (northern Spain). Int. Microbiol. 2021, in press. 
20. Ruíz, J.; Marín-Girón, F.; Ojeda, F.; Marón-Olalla, F.; Berros, J.; Marín-Olalla, E. Estudio macroscópico “in situ” y microscópicoecológico de pequeñas zonas de flora verde (algas verdes y verdeazuladas) del interior de la Cueva de Nerja. In Investigación Biológica y Edafológica de la Cueva de Nerja (Málaga); Marín, F., Carrasco, F., Eds.; Trabajos sobre la Cueva de Nerja: Málaga, Spain, 1992; Volume 2, pp. 113-125.

21. Del Rosal, Y.; Hernández-Mariné, M.; Roldán, M. Phototrophic microorganisms in the tourist cave of Nerja. In Science, Technology and Cultural Heritage; Rogerio-Candelera, M.A., Ed.; CRC Press/Balkema: Leiden, The Netherlands, 2014; pp. $229-234$.

22. Del Rosal Padial, Y.; Jurado Lobo, V.; Hernández Mariné, M.; Roldán Molina, M.; Sáiz Jiménez, C. Biofilms en cuevas turísticas: La Cueva de Nerja y la Cueva del Tesoro. In El Karst y el Hombre: Las Cuevas como Patrimonio Mundial; Andreo, B., Durán, J.J., Eds.; Asociación de Cuevas Turísticas Españolas: Madrid, Spain, 2016; pp. 103-114.

23. Jurado, V.; Del Rosal, Y.; Hernández-Mariné, M.; Galocha Zapata, I.; Domínguez-Moñino, I.; Rogerio Candelera, M.A.; SáizJiménez, C. Biología molecular de los biofilms fotosintéticos de la Cueva de Nerja. In Análisis, Impacto y Evolución de los Biofilms Fotosintéticos en Espeleotemas. El caso de la Cueva de Nerja (Málaga, España); Del Rosal Padial, Y., Ed.; Fundación Pública de Servicios Cueva de Nerja: Nerja, Spain, 2017; pp. 229-270.

24. Jurado, V.; Del Rosal, Y.; Gonzalez-Pimentel, J.L.; Hermosin, B.; Saiz-Jimenez, C. Biological control of phototrophic biofilms in a show cave: The case of Nerja Cave. Appl. Sci. 2020, 10, 3448. [CrossRef]

25. Del Rosal, Y.; Martínez-Manzanares, E.; Marín, F.; Liñán, C.; Simón, M.D. Análisis de la calidad microbiológica aérea en el interior de la Cueva de Nerja. In Cuevas Turísticas: Aportación al Desarrollo Sostenible; Durán, J.J., Robledo, P.A., Vázquez, J., Eds.; Instituto Geológico y Minero de España: Madrid, Spain, 2007; pp. 181-190.

26. Docampo, S.; Trigo, M.M.; Recio, M.; Melgar, M.; Garcia-Sanchez, J.; Calderon-Ezquerro, M.C.; Cabezudo, B. High incidence of Aspergillus and Penicillium spores in the atmosphere of the cave of Nerja (Malaga, southern Spain). Aerobiologia 2010, 26, 89-98. [CrossRef]

27. Docampo, S.; Trigo, M.M.; Recio, M.; Melgar, M.; García-Sánchez, J.; Cabezudo, B. Fungal spores content of the atmosphere of the Cave of Nerja (southern Spain): Diversity and origin. Sci. Total Environ. 2011, 409, 835-843. [CrossRef]

28. Liñán, C.; Del Rosal, Y.; Carrasco, F.; Vadillo, I.; Benavente, J.; Ojeda, L. Highlighting the importance of transitional ventilation regimes in the management of Mediterranean show caves (Nerja-Pintada system, southern Spain). Sci. Total Environ. 2018, 631-632, 1268-1278. [CrossRef] [PubMed]

29. Docampo, S.; Recio, M.; Trigo, M.M.; Cabezudo, B. Risk of pollen allergy in Nerja (southern Spain): A pollen calendar. Aerobiologia 2007, 23, 189-199. [CrossRef]

30. Dominguez-Moñino, I.; Jurado, V.; Rogerio-Candelera, M.A.; Hermosin, B.; Saiz-Jimenez, C. Airborne fungi in show caves from Southern Spain. Appl. Sci. 2021, 11, 5027. [CrossRef]

31. Grbic, M.L.; Vukojevic, J.; Simic, G.S.; Krizmanic, J.; Stupar, M. Biofilm forming cyanobacteria, algae and fungi on two historic monuments in Belgrade, Serbia. Arch. Biol. Sci. 2010, 62, 625-631. [CrossRef]

32. Pfendler, S.; Borderie, F.; Bousta, F.; Alaoui-Sosse, L.; Alaoui-Sosse, B.; Aleya, L. Comparison of biocides, allelopathic substances and UV-C as treatments for biofilm proliferation on heritage monuments. J. Cult. Herit. 2018, 33, 117-124. [CrossRef]

33. De Hoog, G.S. The genera Beauveria, Isaria, Tritirachium and Acrodontium gen. nov. Stud. Mycol. 1972, 1, 1-41.

34. Novakova, A.; Hubka, V.; Saiz-Jimenez, C. Microscopic fungi isolated from cave air and sediments in the Nerja Cave-preliminary results. In The Conservation of Subterranean Cultural Heritage; Saiz-Jimenez, C., Ed.; CRC Press/Balkema: Leiden, The Netherlands, 2014; pp. 239-246.

35. Jurado, V.; Sanchez-Moral, S.; Saiz-Jimenez, C. Entomogenous fungi and the conservation of the cultural heritage: A review. Int. Biodeter. Biodegr. 2008, 62, 325-330. [CrossRef]

36. Leplat, J.; François, A.; Bousta, F. Parengyodontium album, a frequently reported fungal species in the cultural heritage environment. Fungal Biol. Rev. 2020, 34, 126-135. [CrossRef]

37. Bastian, F.; Alabouvette, C.; Saiz-Jimenez, C. The impact of arthropods on fungal community structure in Lascaux Cave. J. Appl. Microbiol. 2009, 106, 1456-1462. [CrossRef] [PubMed]

38. Jurado, V.; Porca, E.; Cuezva, S.; Fernandez-Cortes, A.; Sanchez-Moral, S.; Saiz-Jimenez, C. Fungal outbreak in a show cave. Sci. Total Environ. 2010, 408, 3632-3638. [CrossRef]

39. Porca Belío, E. Aerobiología: Mecanismos de Dispersión de los Microorganismos en Cuevas Turísticas. Ph.D. Thesis, Facultad de Biología, Universidad de Sevilla, Seville, Spain, 2011.

40. Saarela, M.; Alakomi, H.-L.; Suihko, M.-L.; Maunuksela, L.; Raaska, L.; Mattila-Sandholm, T. Heterotrophic microorganisms in air and biofilm samples from Roman catacombs, with special emphasis on actinobacteria and fungi. Int. Biodeter. Biodegr. 2004, 54, 27-37. [CrossRef]

41. Simonovicová, A.; Gódyová, M.; Sevc, J. Airborne and soil microfungi as contaminants of stone in a hypogean cemetery. Int. Biodeter. Biodegr. 2004, 54, 7-11. [CrossRef]

42. Nugari, M.P.; Pietrini, A.M.; Caneva, G.; Imperi, F.; Visca, P. Biodeterioration of mural paintings in a rocky habitat: The Crypt of the Original Sin (Matera, Italy). Int. Biodeter. Biodegr. 2009, 63, 705-711. [CrossRef]

43. Mang, S.M.; Scrano, L.; Camele, I. Preliminary studies on fungal contamination of two rupestrian churches from Matera (Southern Italy). Sustainability 2020, 12, 6988. [CrossRef] 
44. Saiz-Jimenez, C.; Samson, R.A. Microorganisms and environmental pollution as deteriorating agents of the frescoes of "Santa María de la Rábida", Huelva, Spain. In Sixth Triennial Meeting ICOM; Paper 81/15/5; Committee for Conservation: Ottawa, ON, Canada, 1981; p. 14.

45. Gorbushina, A.A.; Petersen, K. Distribution of microorganisms on ancient wall paintings as related to associated faunal elements. Int. Biodeter. Biodegr. 2000, 46, 277-284. [CrossRef]

46. Berner, M.; Wanner, G.; Lubitz, W. A comparative study of the fungal flora present in medieval wall paintings in the chapel of the castle Herberstein and in the parish church of St. Georgen in Styria, Austria. Int. Biodeter. Biodegr. 2004, 40, 53-61. [CrossRef]

47. Barranco, P.; Tinaut, A.; Baena, M. Entomofauna cavernícola de Andalucía. In El Karst de Andalucía. Geoespeleología, Bioespeleología y Presencia Humana; Calaforra Chordi, J.M., Berrocal Pérez, J.A., Eds.; Consejería de Medio Ambiente, Junta de Andalucía: Sevilla, Spain, 2008; pp. 75-85.

48. Gunde-Cimerman, N.; Ramos, J.; Plemenitas, A. Halotolerant and halophilic fungi. Mycol. Res. 2009, 113, 1231-1241. [CrossRef]

49. Nováková, A. Microscopic fungi in caves of the National Park Slovak Karst. Phytopedon 2004, 3, $26-31$.

50. Nováková, A. Microscopic fungi isolated from the Domica Cave system (Slovak Karst National Park, Slovakia). A review. Int. J. Speleol. 2009, 38, 71-82. [CrossRef]

51. Domínguez-Moñino, I.; Jurado, V.; Hermosín, B.; Sáiz-Jiménez, C. Aerobiología de cuevas andaluzas. In Las Cuevas Turísticas como Activos Económicos: Conservación e Innovación; Durán, J.J., Robledo, P.A., Eds.; Asociación de Cuevas Turísticas Españolas: Madrid, Spain, 2012; pp. 299-307.

52. Taylor, E.L.S.; Resende-Stoianoff, M.A.A.; Lopes Ferreira, R. Mycological study for a management plan of a neotropical show cave (Brazil). Int. J. Speleol. 2013, 42, 267-277. [CrossRef]

53. Mitova, M.M.; Iliev, M.; Nováková, A.; Gorbushina, A.A.; Groudeva, V.I.; Martin-Sanchez, P.M. Diversity and biocide susceptibility of fungal assemblages dwelling in the Art Gallery of Magura Cave, Bulgaria. Int. J. Speleol. 2017, 46, 67-80. [CrossRef]

54. Mammola, S.; Di Piazza, S.; Zotti, M.; Isaia, M. Human-induced alterations of the cave mycobiota in an Alpine show cave (ltaly, SW-Alps). Acta Carsologica 2017, 46, 111-123. [CrossRef]

55. Marvanová, L.; Kalouskova, V.; Hanuláková, D.; Scháněl, L. Microscopic fungi in the Zbrašov aragonite caves. Czech Mycol. 1992, $46,243-250$.

56. Novakova, A.; Jurado, V.; Saiz-Jimenez, C. Are fungi a real threat for the conservation of Altamira Cave? In The Conservation of Subterranean Cultural Heritage; Saiz-Jimenez, C., Ed.; CRC Press/Balkema: Leiden, The Netherlands, 2014; pp. $223-228$.

57. Hubka, V.; Nováková, A.; Peterson, S.W.; Frisvad, J.C.; Sklenář, F.; Matsuzawa, T.; Kubátová, A.; Kolarík, M. A reappraisal of Aspergillus section Nidulantes with descriptions of two new sterigmatocystin-producing species. Plant Syst. Evol. 2016, 302, 1267-1299. [CrossRef]

58. Nováková, A.; Hubka, V.; Saiz-Jimenez, C.; Kolarik, M. Aspergillus baeticus sp. nov. and Aspergillus thesauricus sp. nov.: Two new species in section Usti originating from Spanish caves. Int. J. Syst. Evol. Microbiol. 2012, 62, 2778-2785. [CrossRef]

59. Nováková, A.; Kubátová, A.; Sklenář, F.; Hubka, V. Microscopic fungi on cadavers and skeletons from cave and mine environments. Czech Mycol. 2018, 70, 101-121. [CrossRef]

60. Vanderwolf, K.J.; Malloch, D.; McAlpine, D.F.; Forbes, G.J. A world review of fungi, yeasts, and slime molds in caves. Int. J. Speleol. 2013, 42, 77-96. [CrossRef]

61. Popović, S.; Simić, G.S.; Stupar, M.; Unković, N.; Predojević, D.; Jovanović, J.; Grbić, M.L. Cyanobacteria, algae and microfungi present in biofilm from Božana Cave (Serbia). Int. J. Speleol. 2015, 44, 141-149. [CrossRef]

62. Kozlova, E.V.; Mazina, S.E. Biodiversity of fungi in the photic and aphotic zones of Montenegro caves. Aerobiologia 2020, 36, 589-604. [CrossRef]

63. Pusz, W.; Ogórek, R.; Knapik, R.; Kozak, B.; Bujak, H. The occurrence of fungi in the recently discovered Jarkowicka Cave in the Karkonosze Mts. (Poland). Geomicrobiol. J. 2015, 32, 59-67. [CrossRef]

64. Nováková, A.; Hubka, V.; Valinova, S.; Kolarik, M.; Hillebrand-Voiculescu, A.M. Cultivable microscopic fungi from an underground chemosynthesis-based ecosystem: A preliminary study. Folia Microbiol. 2018, 63, 43-55. [CrossRef]

65. Tavares, D.G.; Barbosa, B.V.L.; Ferreira, R.L.; Duarte, W.F.; Cardoso, P.G. Antioxidant activity and phenolic compounds of the extract from pigmentproducing fungi isolated from Brazilian caves. Biocatal. Agric. Biotechnol. 2018, 16, 148-154. [CrossRef]

66. Zhang, Z.F.; Zhou, S.Y.; Eurwilaichitr, L.; Ingsriswang, S.; Raza, M.; Chen, Q.; Zhao, P.; Liu, F.; Cai, L. Culturable mycobiota from Karst caves in China II, with descriptions of 33 new species. Fungal Divers. 2021, 106, 29-136. [CrossRef]

67. Madsen, A.M.; Larsen, S.T.; Koponen, I.K.; Kling, K.I.; Barooni, A.; Karottki, D.G.; Tendal, K.; Wolkoffa, P. Generation and characterization of indoor fungal aerosols for inhalation studies. Appl. Environ. Microbiol. 2016, 82, 2479-2493. [CrossRef]

68. Samson, R.A.; Yilmaz, N.; Houbraken, J.; Spierenburg, H.; Seifert, K.A.; Peterson, S.W.; Varga, J.; Frisvad, J.C. Phylogeny and nomenclature of the genus Talaromyces and taxa accommodated in Penicillium subgenus Biverticillium. Stud. Mycol. 2011, 70, 159-183. [CrossRef] [PubMed]

69. Shibata, S.; Udagawa, S. Metabolic products of fungi. XIX. Isolation of rugulosin from Penicillium brunneum Udagawa. Chem. Pharm. Bull. 1963, 11, 402-403. [CrossRef]

70. Paula, C.C.P.; Montoya, Q.V.; Meirelles, L.A.; Sanchez, C.F.; Rodrigues, A.; Seleghim, M.H.R. High cellulolytic activities in filamentous fungi isolated from an extreme oligotrophic subterranean environment (Catão cave) in Brazil. An. Acad. Bras. Cienc. 2019, 91, e20180583. [CrossRef] [PubMed] 
71. Jiang, J.-R.; Cai, L.; Liu, F. Oligotrophic fungi from a carbonate cave, with three new species of Cephalotrichum. Mycology 2017, 8, 164-177. [CrossRef]

72. Razafinarivo, J.; Jany, J.-L.; Crous, P.W.; Looten, R.; Gaydou, V.; Barbier, G.; Mounier, J.; Vasseur, V. Cladosporium lebrasiae, a new fungal species isolated from milk bread rolls in France. Fungal Biol. 2016, 120, 1017-1029. [CrossRef]

73. Zalar, P.; de Hoog, G.S.; Schroers, H.-J.; Crous, P.W.; Groenewald, J.Z.; Gunde-Cimerman, N. Phylogeny and ecology of the ubiquitous saprobe Cladosporium sphaerospermum, with descriptions of seven new species from hypersaline environments. Stud. Mycol. 2007, 58, 157-183. [CrossRef]

74. Manamgoda, D.S.; Rossman, A.Y.; Castlebury, L.A.; Crous, P.W.; Madrid, H.; Chukeatirote, E.; Hyde, K.D. The genus Bipolaris. Stud. Mycol. 2014, 79, 221-288. [CrossRef]

75. Wang, M.; Tan, X.-M.; Liu, F.; Cai, L. Eight new Arthrinium species from China. MycoKeys 2018, 34, 1-24. [CrossRef]

76. Saiz-Jimenez, C. Cave Conservation: A Microbiologist's Perspective. In Cave Microbiomes: A Novel Resource for Drug Discovery; Cheepham, N., Ed.; SpringerBrief in Microbiology 1: New York, NY, USA, 2013; pp. 69-84.

77. Zhang, Z.F.; Liu, F.; Zhou, X.; Liu, X.Z.; Liu, S.J.; Cai, L. Culturable mycobiota from Karst caves in China, with descriptions of 20 new species. Persoonia 2017, 39, 1-31. [CrossRef]

78. Belyagoubi, L.; Belyagoubi-Benhammou, N.; Jurado, V.; Dupont, J.; Lacoste, S.; Djebbah, F.; Ounadjela, F.Z.; Benaissa, S.; Habi, S.; Abdelouahi, D.E.; et al. Antimicrobial activities of culturable microorganisms (actinomycetes and fungi) isolated from Chaabe Cave, Algeria. Int. J. Speleol. 2018, 47, 189-199. [CrossRef]

79. Woudenberg, J.H.C.; Meijer, M.; Houbraken, J.; Samson, R.A. Scopulariopsis and scopulariopsis-like species from indoor environments. Stud. Mycol. 2017, 88, 1-35. [CrossRef]

80. Larcher, G.; Bouchara, J.P.; Pailley, P.; Montfort, D.; Beguin, H.; De Biève, C.; Chabasse, D. Fungal biota associated with bats in Western France. J. Med. Mycol. 2003, 13, 29-34.

81. Vaughan-Martini, A.; Angelini, P.; Zacchi, L. The influence of human and animal visitation on the yeast ecology of three Italian caverns. Ann. Microbiol. 2000, 50, 133-140.

82. Sugita, T.; Kikuchi, K.; Makimura, K.; Urata, K.; Someya, T.; Kamei, K.; Niimi, M.; Uehara, Y. Trichosporon species isolated from guano samples obtained from bat-inshabited caves in Japan. Appl. Environ. Microbiol. 2005, 71, 7626-7629. [CrossRef] [PubMed]

83. Gómez de Ana, S.; Torres-Rodríguez, J.M.; Ramírez, E.A.; Belmonte-Soler, J. Seasonal distribution of Alternaria, Aspergillus, Cladosporium and Penicillium species isolated in homes of fungal allergic patients. J. Investig. Allergol. Clin. Immunol. 2006, 16, 357-363.

84. Hurst, C.J. Understanding Terrestrial Microbial Communities; Springer: Cham, Switzerland, 2019.

85. Davolos, D.; Pietrangeli, B.; Persiani, A.M.; Maggi, O. Victoriomyces antarcticus gen. nov., sp. nov., a distinct evolutionary lineage of the Cephalothecaceae (Ascomycota) based on sequence-based phylogeny and morphology. Int. J. Syst. Evol. Microbiol. 2019, 69, 1099-1110. [CrossRef] [PubMed]

86. Mapook, A.; Hyde, K.D.; McKenzie, E.H.C.; Jones, E.B.G.; Bhat, D.J.; Jeewon, R.; Stadler, M.; Samarakoon, M.C.; Malaithong, M.; Tanunchai, B.; et al. Taxonomic and phylogenetic contributions to fungi associated with the invasive weed Chromolaena odorata (Siam weed). Fungal Divers. 2020, 101, 1-175. [CrossRef]

87. Sandoval-Denis, M.; Gené, J.; Sutton, D.A.; Cano-Lira, J.F.; de Hoog, G.S.; Decock, C.A.; Wiederhold, N.P.; Guarro, J. Redefining Microascus, Scopulariopsis and allied genera. Persoonia 2016, 36, 1-36. [CrossRef]

88. Melo, A.G.; Souza, P.N.C.; Maia, N.C.; Thomas, A.B.; Silva, L.B.R.; Batista, L.R.; Ferreira, R.L.; Cardoso, P.G. Screening and identification of tannase-producing fungi isolated from Brazilian caves. African J. Microbiol. Res. 2013, 7, 483-487.

89. Cunha, A.O.B.; Bezerra, J.D.P.; Oliveira, T.G.L.; Barbier, E.; Bernard, E.; Machado, A.R.; Souza-Motta, C.M. Living in the dark: Bat caves as hotspots of fungal diversity. PLoS ONE 2020, 15, e243494. [CrossRef] [PubMed]

90. Trovão, J.; Mesquita, N.; Paiva, D.S.; Carvalho, H.P.; Avelar, L.; Portugal, A. Can arthropods act as vectors of fungal dispersion in heritage collections? A case study on the archive of the University of Coimbra, Portugal. Int. Biodeter. Biodegr. 2013, 79, 49-55. [CrossRef]

91. Jaber, S.; Mercier, A.; Knio, K.; Brum, S.; Kambris, Z. Isolation of fungi from dead arthropods and identification of a new mosquito natural pathogen. Parasite Vector 2016, 9, 491. [CrossRef] [PubMed]

92. Yun, T.-S.; Park, S.Y.; Yu, J.; Hwang, Y.; Hong, K.-J. Isolation and identification of fungal species from the insect pest Tribolium castaneum in rice processing complexes in Korea. Plant Pathol. J. 2018, 34, 356-366. [CrossRef]

93. Jenoh, E.M.; de Villiers, E.P.; de Villiers, S.M.; Okoth, S.; Jefwa, J.; Kioko, E.; Kaimenyi, D.; Hendrickx, M.; Dahdouh-Guebas, F.; Koedam, N. Infestation mechanisms of two woodborer species in the mangrove Sonneratia alba J. Smith in Kenya and co-occurring endophytic fungi. PLoS ONE 2019, 14, e0221285. [CrossRef]

94. Hubka, V.; Nováková, A.; Kolarík, M.; Jurjević, A.; Peterson, S.W. Revision of Aspergillus section Flavipedes: Seven new species and proposal of section Jani sect. nov. Mycologia 2015, 107, 169-208. [CrossRef]

95. Dominguez-Moñino, I.; Jurado, V.; Hermosin, B.; Saiz-Jimenez, C. Paracoccus cavernae sp. nov., isolated from a show cave. Int. J. Syst. Evol. Microbiol. 2016, 66, 1-6. [CrossRef] [PubMed]

96. Dominguez-Moñino, I.; Jurado, V.; Gonzalez-Pimentel, J.L.; Miller, A.Z.; Hermosin, B.; Saiz-Jimenez, C. Bacillus onubensis sp. nov. isolated from the air of two Andalusian caves. Syst. Appl. Microbiol. 2018, 41, 167-172. [CrossRef] [PubMed] 